\title{
Treatment of wheat seed with zinc, fungicide, and polymer: seed quality and yield ${ }^{1}$
}

\author{
Cassyo Araujo Rufino ${ }^{2 *}$, Lizandro Ciciliano Tavares², André Pich Brunes², \\ Elisa Souza Lemes ${ }^{2}$, Francisco Amaral Villela ${ }^{2}$
}

\begin{abstract}
The objective of this study was to assess performance of wheat seeds after application of three components [fungicide, zinc (Zn), and polymer], separately or with their combinations, as well as assessing seed quality and yield. Thus, the treatments consisted in combinations of fungicide + zinc $(\mathrm{Zn})+$ polymer, totaling six treatments, with four replicates per treatment, as follow: T0 - without application of Zn, fungicide, or polymer (control); T1 - Zn; T2 - Zn + polymer; T3 - polymer; T4 - fungicide; T5 - polymer + fungicide; and T6 - Zn + polymer + fungicide. The performance of the seeds originating from plants whose seeds had been pre-treated was assessed by tests of germination and vigor, in addition to analyzes of growth and yield. It was concluded that wheat seeds treated with zinc, fungicide and polymer are positively influenced until 30 days after emergence. The germination of wheat seeds is positively influenced by the treatment with fungicide, as much when separately applied as in combined application with zinc and polymer. The yield per plant increases when seeds are treated with $\mathrm{Zn}$.
\end{abstract}

Index terms: Triticum aestivum L, germination, vigor.

\section{Tratamento de sementes de trigo com zinco, fungicida e polímero: qualidade e rendimento de sementes}

\begin{abstract}
RESUMO - O objetivo deste estudo foi avaliar o desempenho de sementes de trigo após a aplicação de três componentes [fungicida, zinco $(\mathrm{Zn})$ e polímero] isoladamente, ou com a combinação destes produtos, bem como avaliar a qualidade e o rendimento das sementes produzidas. Deste modo, os tratamentos consistiram nas combinações de fungicida $+\mathrm{Zn}+$ polímero, totalizando seis tratamentos, com quatro repetições para cada tratamento: T0 - sem aplicação de Zn, fungicida ou polímero (testemunha); T1 - Zn; T2 - Zn + polímero; T3 - polímero; T4 - fungicida; T5- polímero + fungicida; e T6- Zn + polímero + fungicida. O desempenho das sementes produzidas, oriundas das sementes tratadas, foi avaliado por testes de vigor e germinação, além de análises de crescimento e rendimento. Pelos resultados obtidos conclui-se que sementes de trigo tratadas com Zn, fungicida e polímero são positivamente influenciadas até 30 dias após a emergência. A germinação das sementes é positivamente influenciada pelo tratamento com fungicida, tanto quando este é aplicado isoladamente quanto em aplicação combinada com Zn e polímero. O rendimento por planta aumenta quando as sementes de trigo são tratadas com Zn.
\end{abstract}

Termos para indexação: Triticum aestivum, germinação, vigor.

\section{Introduction}

In the 2010/2011 crop, wheat production in Brazil was approximately 5.8 million tons of grains, with an increase of $17 \%$ as related to previous harvest. The State of Paraná is the largest nationwide wheat producer with approximately 3.3 million tons produced, followed by State of Rio Grande do Sul, second national producer, with a production of 1.9 million tons, equivalent to approximately one third of nationwide production (CONAB, 2011).
Among aspects related to production of wheat, such as choice of cultivar, type of cultivation and climate, and type of fertilization deserve especial care, chiefly in relation to micronutrients. Among these microelements, zinc can be highlighted and its deficiency can cause reduction on rate of plant growth, by limiting expansion of leaves; in addition to elongation of plant stems, and restriction of root growth (Bergmann, 1992), consequently determining reduction on yield. Zinc is the micronutrient that most frequently has proved to be deficient in Brazilian soils (Ribeiro and Santos, 1996),

\footnotetext{
${ }^{1}$ Submitted on 06/06/2012. Accepted for publication on 09/27/2012.

${ }^{2}$ Departamento de Ciência e Tecnologia de Sementes, Universidade Federal de Pelotas, Caixa Postal 354, 96001-970 - Pelotas, RS, Brasil.

*Corresponding author <cassyo.araujo@yahoo.com.br>
} 
especially in presence of heavy phosphate fertilizations (Barbosa-Filho et al., 1994).

Zinc is an enzymatic activator responsible for growth of the plant species and by maturation of their fruits. The zinc-deficient plants present evident symptoms chiefly on youngest parts of plants (Vitti and Serrano, 2007). To be efficient, the seed treatment with zinc has as a basic principle its translocation to whole plant. Thus, zinc reserves become important by preventing initial symptoms of deficiency (Ribeiro and Santos, 1996). Application of zinc on seeds has effect on germination and on initial growth of seedling, as well as favors physiological quality of the seeds produced (Santos, 1981); in addition, allowing high uniformity in distribution of seedlings in field, cost reduction on transport of seeds to field and its own application, besides rationalizing use of reserves of non-renewable minerals.

The absorption of the zinc applied to seeds occurs almost in its totality, thus increasing reserves of this element in the seeds. Plants grown under low-zinc conditions, generally produce seeds with low content and concentration of zinc that, when sowed in zinc-deficient soil, will originate less vigorous seedlings; what will be reflected on the low yield at harvest. The increase of zinc content in the seeds has positive effect on increment of yield of plants grown under this conditions (Genc et al., 2000). The zinc application on seeds of sorghum in relatively small amounts via pre-conditioning may be a promising form of fertilization; as it has been studied for other grasses such as corn and rice (Ribeiro and Santos, 1996). The practice of adding zinc to seeds favors uniformity of application and places the element in immediate contact with the first emitted roots (Barbosa-Filho et al., 1982). In upland rice cultivation, these same researchers have observed that application of $10 \mathrm{~kg} \cdot \mathrm{ha}^{-1}$ of zinc in the sowing furrow, and/ or application of a $1 \%$ zinc solution on the seeds showed no statistically significant difference on grain yield.

The use of polymers jointly with application of several nutrients is being studied by many researchers. In cotton, Lima et al. (2006) have found an interaction between the factors "coating films and chemical treatment of seeds", and they have concluded that seed coating did not negatively impair seed physiological quality; besides providing better adherence of chemical product on the seeds. It is a consensus among researchers that the supply of zinc through seed treatment is one of the best modes of product application, due to the little amounts required by plants, better uniformity of distribution, and lower cost of application, as well as of guarantee that nutrition of the plants in initial growth stage, in which the root system is little developed, they are positively affected by absorption of zinc from soil (Bonnecarrère et al., 2004).
In this context, the objective of this study were to assess behavior of wheat seeds after application of zinc, fungicide, and polymer, and each one of them alone or in combination; besides verifying quality and yield of the seeds produced.

\section{Material and Methods}

The experiment was carried out in the Didactic Laboratory of Seed Analysis and under greenhouse conditions, both belonging to the College of Agronomy Eliseu Maciel of Federal University of Pelotas, Pelotas, State of Rio Grande do

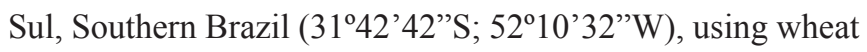
cultivar BRS "Guamirim".

Treatments consisted in application of $\mathrm{Zn}$, fungicide, and polymer, separately or jointly, thus totaling seven treatments, with four replications per treatment, as following described: T0 - without application of Zn, fungicide, or polymer (control); T1 - Zn; T2 - Zn + polymer; T3 - polymer; T4 - fungicide; $\mathrm{T} 5$ - polymer + fungicide; and $\mathrm{T} 6-\mathrm{Zn}+$ fungicide + polymer.

The seeds were treated with products applied in the following order: fungicide Maxim-XL ${ }^{\circledR}$ in dose of $1 \mathrm{~mL} \cdot \mathrm{kg}^{-1}$ of seed; polymer Sepiret ${ }^{\circledR}$ in dose of $2.5 \mathrm{~mL} \cdot \mathrm{kg}^{-1}$ of seed; and a zinc-based product with 780 g. $\mathrm{L}^{-1}$ of zinc, in dose of $2 \mathrm{~mL} . \mathrm{kg}^{-1}$ of seed. The spray volume used was $8 \mathrm{~mL} \cdot \mathrm{kg}^{-1}$ of seed, keeping this proportion with water. The products were directly placed in bottom of a plastic bag until $10 \mathrm{~cm}$ in height. Immediately after, $200 \mathrm{~g}$ of seeds was placed inside the plastic bag, which was then shaken during $3 \mathrm{~min}$. In sequence, seeds were placed to dry at room temperature, during $24 \mathrm{~h}$ (Nunes, 2005). These treated seeds were used to assess physiological quality before sowing and then cultivated until harvest. After harvest, physiological quality was assessed in the seeds produced by plants originated from seeds previously treated in the same way.

After coating, the physiological quality of these seeds was assessed by following tests:

Germination $(G)$ : this test was performed with four replications of 50 seeds each, for each seed sample. For this, the seeds were distributed on top of two sheets of Germitest ${ }^{\circledR}$ paper, previously moistened with distilled water in a ratio equivalent to 2.5 the mass of dry substrate, and covered with another sheet. The rolls were kept into a seed germinator, at $20^{\circ} \mathrm{C}$. Assessments were performed at eight days after seeding according to Rules for Seed Testing (Brasil, 2009) and results were expressed in percentage of normal seedling.

First count of germination ( $F C G$ ): such assessment was performed at the fourth day after seeding during conduction of germination test.

Accelerated aging (AA): seeds were distributed over an aluminum screen placed inside a plastic box (gerbox), 
containing $40 \mathrm{~mL}$ of water, maintained at $41{ }^{\circ} \mathrm{C}$ at a BOD incubator for 72 hours. After such period, seeds were subjected to germination test and normal seedlings percentage was assessed at the fourth day after seeding.

Cold test (CT): it was conducted with four subsamples of 50 seeds each, for each sample following methodology described for germination test. However, with the paper rolls placed into plastic bags, which were closed and kept into an incubator at $10{ }^{\circ} \mathrm{C}$, during seven days. After this period, the rolls with seeds were transferred to a seed germinator and kept at $20^{\circ} \mathrm{C}$, and germination was assessed after four days (Cícero and Vieira, 1994).

The seed sowing was also carried out under greenhouse conditions, by using $15 \mathrm{~L}$ capacity pots filled with sifted soil. The soil fertilization was performed following recommendations of soil analysis, of Commission for Recommendations of Chemistry and Fertility of soil for states of Rio Grande do Sul and Santa Catarina (2004), and Manual of Technical Information for Wheat and Triticale (season crop 2010). Nitrogen, phosphorus, and potassium were applied 14 days before sowing. The experimental units were daily irrigated keeping soil moisture close to the field capacity. Twelve seeds were sown per pot, leaving only seven plants per pot after thinning. The samples for assessing initial growth took into account the following variables: leaf area (LA); plant height $(\mathrm{PH})$; and dry phytomass of the aerial parts (DPAP). For these determinations, one plant per pot was randomly collected at every 10,20, and 30 days after emergence (DAE) by cutting such plant at the soil level. The LA was determined by using a photoelectric leaf area meter (brand Li-cor; model LI-3100) that provides direct reading in $\mathrm{cm}^{2}$. For determining PH the measurement was performed with graduated ruler in millimeters with results expressed in $\mathrm{cm}$. The DPAP was performed by the oven method at $60{ }^{\circ} \mathrm{C}$, inside which the seedlings were kept for a period of $72 \mathrm{~h}$, and then weighed in an analytical balance with centesimal precision. With the results achieved in assessing leaf area and dry phytomass of aerial parts the following parameters were determined: crop growth rate - CGR (mg.day $\left.{ }^{-1}\right)$; relative growth rate - RGR (mg. $\mathrm{g}^{-1}$.day $\mathrm{d}^{-1}$ ); and liquid assimilation rate - LAR $\left(\mathrm{mg} . \mathrm{cm}^{-2}\right.$.days $\left.\mathrm{s}^{-1}\right)$. These determinations were based on the equations described by Gardner et al. (1985), which are: CGR = $(\mathrm{DM} 2-\mathrm{DM} 1) /(\mathrm{T} 2-\mathrm{T} 1): \mathrm{RGR}=(\ln \mathrm{DM} 2-(\ln \mathrm{DM} 1) /(\mathrm{T} 2-\mathrm{T} 1)$; $\mathrm{LAR}=(\mathrm{DM} 2-\mathrm{DM} 1) /(\mathrm{T} 1-\mathrm{T} 1) *(\ln \mathrm{LA} 2-\ln \mathrm{LA} 1) /(\mathrm{LA} 2-$ LA1); Where DM = dry mass; $\mathrm{T}=$ time; and $\mathrm{LA}=$ leaf area.

The harvest was manually performed at reproductive stage in which two thirds of wheat spikes was presenting lightbrown or cream coloration, thus characterizing physiological maturity. The quality of seeds produced was assessed by the tests: FCG, G, and AA as previously described; in addition to: hectoliter weight $(\mathrm{HW})$ that was obtained by analysis performed in three replications and measured with a specific scale, with capacity of one liter of seeds, with result expressed in $\mathrm{kg} \cdot \mathrm{hL}^{-1}$; and yield (Y), obtained by weight of the seed harvested manually, and by correcting moisture content to $13 \%$.

A completely randomized experimental design was used with six treatments and four replications; and data were subjected to ANOVA. Means were compared by Tukey tests, at $5 \%$ probability. To perform statistical analysis it was used the Winstat Statistical Analysis System, Version 1.0 (Machado and Conceição, 2003).

\section{Results and Discussion}

In Table 1, results for FCG, G, CT, and AA are presented. In germination test, the treatment of seeds with fungicide and polymer presented better results than when seeds were treated with $\mathrm{Zn}+$ fungicide. However, when the FCG was assessed, the same results were obtained for treatments with polymer and fungicide; although it is also possible to verify that control treatment and the treatment with $\mathrm{Zn}+$ fungicide + polymer both have produced results lower than those obtained in the formerly mentioned treatments.

Table 1. Results obtained for the variables: first count of germination (FCG), germination $(\mathrm{G})$, cold test (CT), and accelerated aging (AA) collected in tests performed with wheat seeds, cv. BRS "Guamirim" without treatment and treated with different products.

\begin{tabular}{lcccc}
\hline \multirow{2}{*}{\multicolumn{1}{c}{ Treatment }} & \multicolumn{4}{c}{ Variable assessed } \\
\cline { 2 - 5 } & $\begin{array}{c}\text { FCG } \\
(\%)\end{array}$ & $\begin{array}{c}\mathrm{G} \\
(\%)\end{array}$ & $\begin{array}{c}\mathrm{CT} \\
(\%)\end{array}$ & $\begin{array}{c}\text { AA } \\
(\%)\end{array}$ \\
\hline Without treatment (control) & $80 \mathrm{~b}^{*}$ & $86 \mathrm{ab} *$ & $78 \mathrm{~b}^{*}$ & $59 \mathrm{~b}^{*}$ \\
Zn & $87 \mathrm{ab}$ & $89 \mathrm{ab}$ & $82 \mathrm{ab}$ & $85 \mathrm{a}$ \\
Zn + Polymer & $84 \mathrm{ab}$ & $84 \mathrm{~b}$ & $86 \mathrm{ab}$ & $76 \mathrm{~b}$ \\
Polymer & $90 \mathrm{a}$ & $92 \mathrm{a}$ & $88 \mathrm{ab}$ & $65 \mathrm{~b}$ \\
Fungicide & $90 \mathrm{a}$ & $92 \mathrm{a}$ & $89 \mathrm{ab}$ & $85 \mathrm{a}$ \\
Fungicide + Polymer & $83 \mathrm{ab}$ & $88 \mathrm{ab}$ & $87 \mathrm{ab}$ & $79 \mathrm{a}$ \\
Zn + Fungicide + Polymer & $81 \mathrm{~b}$ & $86 \mathrm{ab}$ & $91 \mathrm{a}$ & $80 \mathrm{a}$ \\
\hline \multicolumn{1}{c}{ Mean } & 85 & 88 & 86 & 76 \\
\hline \multicolumn{1}{c}{ CV (\%) } & 6.5 & 6.1 & 6.3 & 9.4 \\
\hline
\end{tabular}

* Means followed by the same letter in the columns do not statistically differ between each other by Tukey test, at $5 \%$ probability.

In $\mathrm{CT}$, seeds subjected to pre-treatment using combination of $\mathrm{Zn}+$ fungicide + polymer showed higher performance than non-treated seeds. In AA test, seeds non-treated, but coated with $\mathrm{Zn}+$ polymer and polymer alone, have showed 
lower performance than the seeds that submitted to others treatments. In rice seeds coated with zinc, fungicide, and polymer, Funguetto et al., (2010) also have not found alterations on seed germination. However, Yagi et al. (2006) have detected decrease on germination of sorghum seeds treated with zinc. Analyzing results achieved in this study it can be inferred that by lack of protection of polymer on the seeds, forming a protecting pellicle on the seeds treated with zinc, fungicide, and polymer, these seeds have presented lower capacity to germinate under the stresses conditions caused by high temperature.
On table 2 are presented results for initial growth of wheat seedlings assessed at 10,20 and 30 DAE and which are originated from seeds treated with zinc, fungicide and polymer. As it can be noticed through the data presented in that table, the seeds treated with zinc have produced plants with $\mathrm{PH}, \mathrm{LA}$, and DFAP, higher than plants from the remaining treatments when assessed at the tenth DAE. The efficiency of treatment with zinc has been also detected by Ribeiro e Santos, (1996) who, in studies with application of small doses of zinc via sorghum seeds have likewise found improvement on growth of other plants species, such as corn and rice.

Table 2. Results obtained for the variables: plant height (PH); leaf area (LA); and dry mass of aerial parts (DMAP) of wheat plants, cv. BRS "Guamirim", from seeds without treatment or treated with different products, and assessed in 10, 20, and 30 days after emergence (DAE).

\begin{tabular}{|c|c|c|c|c|}
\hline \multirow{2}{*}{$\begin{array}{c}\text { Assessment } \\
\text { periods }\end{array}$} & \multirow{2}{*}{ Treatment } & \multicolumn{3}{|c|}{ Variables assessed } \\
\hline & & $\mathrm{PH}(\mathrm{cm})$ & $\mathrm{LA}\left(\mathrm{cm}^{2}\right)$ & DMAP (mg) \\
\hline \multirow{7}{*}{$10 \mathrm{DAE}$} & Without treatment (control) & $17.8 b^{*}$ & $5.7 b^{*}$ & $25 \mathrm{~b}^{*}$ \\
\hline & $\mathrm{Zn}$ & $19.1 \mathrm{ab}$ & $6.0 \mathrm{ab}$ & $28 \mathrm{ab}$ \\
\hline & $\mathrm{Zn}+$ Polymer & $18.9 \mathrm{~b}$ & $6.0 \mathrm{ab}$ & $31 \mathrm{ab}$ \\
\hline & Polymer & $18.9 \mathrm{~b}$ & $5.7 \mathrm{~b}$ & $29 \mathrm{~b}$ \\
\hline & Fungicide & $18.7 \mathrm{~b}$ & $6.0 \mathrm{~b}$ & $27 \mathrm{~b}$ \\
\hline & Fungicide + Polymer & $18.0 \mathrm{~b}$ & $5.1 \mathrm{~b}$ & $24 \mathrm{~b}$ \\
\hline & $\mathrm{Zn}+$ Fungicide + Polymer & $22.0 \mathrm{a}$ & $7.3 \mathrm{a}$ & $37 \mathrm{a}$ \\
\hline & Mean & 19.0 & 6.0 & 28 \\
\hline & C.V. $(\%)$ & 6.9 & 9.9 & 12.7 \\
\hline \multirow{7}{*}{$20 \mathrm{DAE}$} & Without treatment (control) & $25.1 \mathrm{a}$ & $15.7 \mathrm{ab}$ & $76 \mathrm{ab}$ \\
\hline & $\mathrm{Zn}$ & $28.2 \mathrm{a}$ & $13.0 \mathrm{~b}$ & $62 \mathrm{~b}$ \\
\hline & $\mathrm{Zn}+$ Polymer & $27.8 \mathrm{a}$ & $15.9 \mathrm{ab}$ & $82 \mathrm{ab}$ \\
\hline & Polymer & $29.1 \mathrm{a}$ & $16.4 \mathrm{a}$ & $87 \mathrm{a}$ \\
\hline & Fungicide & $26.8 \mathrm{a}$ & $14.7 \mathrm{~b}$ & $81 \mathrm{ab}$ \\
\hline & Fungicide + Polymer & $27.5 \mathrm{a}$ & $15.1 \mathrm{ab}$ & $77 \mathrm{ab}$ \\
\hline & Zn + Fungicide + Polymer & $29.2 \mathrm{a}$ & $15.4 \mathrm{ab}$ & $86 \mathrm{a}$ \\
\hline & Mean & 28.7 & 15.6 & 78 \\
\hline & C.V. $(\%)$ & 7.1 & 13.0 & 9.4 \\
\hline \multirow{9}{*}{$30 \mathrm{DAE}$} & Without treatment (control) & $32.0 \mathrm{a}$ & 44. b & $211 \mathrm{~b}$ \\
\hline & $\mathrm{Zn}$ & $33.6 \mathrm{a}$ & $54.4 \mathrm{ab}$ & $224 \mathrm{~b}$ \\
\hline & $\mathrm{Zn}+$ Polymer & $32.8 \mathrm{a}$ & $53.5 \mathrm{~b}$ & $253 \mathrm{~b}$ \\
\hline & Polymer & $33.5 \mathrm{a}$ & $49.1 \mathrm{~b}$ & $224 b$ \\
\hline & Fungicide & $35.1 \mathrm{a}$ & $46.7 \mathrm{ab}$ & $230 \mathrm{ab}$ \\
\hline & Fungicide + Polymer & $33.4 \mathrm{a}$ & $61.3 \mathrm{a}$ & $251 \mathrm{ab}$ \\
\hline & $\mathrm{Zn}+$ Fungicide + Polymer & $31.5 \mathrm{a}$ & $64.7 \mathrm{a}$ & $300 \mathrm{a}$ \\
\hline & Mean & 32.7 & 53.4 & 241 \\
\hline & C.V. $(\%)$ & 5.7 & & 13.3 \\
\hline
\end{tabular}

* Means followed by the same letter in the columns do not statistically differ between each other, in each variable and period assessed, by Tukey test, at $5 \%$ probability.

The treatment of seeds with combinations of zinc with fungicide and polymer have not induced statistically significant differences in the assessment performed at $20 \mathrm{DAE}$ for the PH variable; while for LA and DPAP the treatment with polymer alone has presented higher performance. Results for LA showed that the coating with polymer alone has promoted the best response. However, for DPAP it was found that seeds coated with the polymer alone or with the combination of $\mathrm{Zn}$ 
+ fungicide + polymer promoted the highest production of dry matter, higher than the production obtained for remaining treatments. These results corroborate results obtained by Coutinho et al. (2001), in which was evidenced that application of zinc in pre-treatment of seeds promotes increments of: dry phytomass, and content of zinc in aerial parts; as well as accumulation of zinc and micronutrients in aerial parts.

In relation to the assessments performed at $30 \mathrm{DAE}$, it was not found statistically significant differences among treatments for the PH variable. Nevertheless, for the variable LA the combinations of fungicide + polymer and of $\mathrm{Zn}+$ fungicide + polymer have presented the best results. For DPAP, treatment with the combination of $\mathrm{Zn}+$ fungicide + polymer was the one that promoted the best performance of wheat plants; although with results similar to those found in treatments with fungicide and with fungicide + polymer. The results corroborate results found by Prado et al. (2007), they have found increase on initial performance of corn seedlings, after treatment of seeds with zinc sulfate $\left(\mathrm{ZnSO}_{4}\right)$.

On Table 3 are shown results of assessments performed to determine growth of wheat plants, originating from treatment of seeds with the combination of zinc with fungicide and polymer. The CGR represents the gain of dry matter in function of assessments periods; and by data shown, it is possible to demonstrate that treatment of seeds with the combination of $\mathrm{Zn}+$ fungicide + polymer was higher in the three periods of assessment studied; thus demonstrating the positive influence of this treatment on initial growth of wheat plants.

The CGR represents the variation on dry mass in function of initial dry mass within an interval of time; and by data presented on Table 3, it is possible verifying that the wheat seeds treated with polymer produced plants with higher CGR. The LAR expresses dry mass produced by leaf area unit per unit of time; and within the period of 11 to 20 DAE (Table 3) it is observed that wheat seeds treated only with polymer have produced plants with higher LAR. However, in the period of 21 to $30 \mathrm{DAE}$, it can be observed the significant effect of treatment with combination of $\mathrm{Zn}+$ fungicide + polymer; which were higher than other treatments. This allows inferring that after $20 \mathrm{DAE}$, the plants were able to absorb the applied products, chiefly zinc.

In relation to yield and quality of the seeds produced (Table 4), which were originated from seeds treated with the combination of zinc + fungicide + polymer, it can be verified the positive influence on yield, first count of germination, and germination. It also can be noticed that treatment of seeds with zinc alone has provided significant increase on yield. These results agree with those results obtained by Ohse et al. (1997) that have observed that number of panicles per rice plants, varied in function of the zinc dose applied to the seeds; for a maximum estimated number of 5.94 panicles per plant using the optimal dose estimated of $0.76 \mathrm{~g}$ of Zn.kg-1 of seed, equivalent to $114.0 \mathrm{~g} \cdot \mathrm{ha}^{-1}$ of zinc. However, Funguetto et al. (2010) on rice seeds and OrioliJunior et al. (2008) on seeds of wheat, statistically significant differences among doses of zinc have not been observed; indicating that have not occurred differences on the number of wheat spikes treated with zinc.

Table 3. Results obtained for the variables: crop growth rate (CGR); relative growth rate (RGR); and liquid assimilation rate (LAR) of wheat plants, cv. BRS "Guamirim", from seeds previously treated with different products, and assessed at intervals of 1 to 10 , 11 to 20 , and 21 to 30 days after emergence (DAE).

\begin{tabular}{|c|c|c|c|}
\hline \multirow{3}{*}{ Treatment } & \multicolumn{3}{|c|}{ Assessment period } \\
\hline & $1-10$ & $11-20$ & $21-30$ \\
\hline & DAE & DAE & DAE \\
\hline & \multicolumn{3}{|c|}{ CGR (mg.pl ${ }^{-1} \cdot$ day $\left.^{-1}\right)$} \\
\hline Without treatment (control) & $25 b^{*}$ & $73 \mathrm{ab}^{*}$ & $0.20 \mathrm{~b}^{*}$ \\
\hline $\mathrm{Zn}$ & $28 \mathrm{~b}$ & $59 \mathrm{~b}$ & $0.21 \mathrm{~b}$ \\
\hline $\mathrm{Zn}+$ Polymer & $31 \mathrm{ab}$ & $78 a b$ & $0.24 \mathrm{ab}$ \\
\hline Polymer & $29 a b$ & $74 a b$ & $0.21 \mathrm{~b}$ \\
\hline Fungicide & $27 \mathrm{~b}$ & $78 \mathrm{ab}$ & $0.22 \mathrm{ab}$ \\
\hline Fungicide + Polymer & $24 \mathrm{~b}$ & $75 \mathrm{ab}$ & $0.24 \mathrm{ab}$ \\
\hline $\mathrm{Zn}+$ Fungicide + Polymer & $37 \mathrm{a}$ & $83 \mathrm{a}$ & $0.29 \mathrm{a}$ \\
\hline Mean & 29 & 76 & 0.23 \\
\hline \multirow[t]{2}{*}{ CV $(\%)$} & 12.7 & 11.3 & 13.7 \\
\hline & \multicolumn{3}{|c|}{ RGR (mg.g ${ }^{-1}$.day $\left.{ }^{-1}\right)$} \\
\hline Without treatment (control) & - & $0.11 \mathrm{a}$ & $0.10 \mathrm{a}$ \\
\hline $\mathrm{Zn}$ & - & $0.07 \mathrm{a}$ & $0.12 \mathrm{a}$ \\
\hline $\mathrm{Zn}+$ Polymer & - & $0.09 \mathrm{a}$ & $0.11 \mathrm{a}$ \\
\hline Polymer & - & $0.10 \mathrm{a}$ & $0.09 \mathrm{a}$ \\
\hline Fungicide & - & $0.10 \mathrm{a}$ & $0.10 \mathrm{a}$ \\
\hline Fungicide + Polymer & - & $0.11 \mathrm{a}$ & $0.11 \mathrm{a}$ \\
\hline $\mathrm{Zn}+$ Fungicide + Polymer & - & $0.08 \mathrm{a}$ & $0.12 \mathrm{a}$ \\
\hline Mean & - & 0.10 & 0.11 \\
\hline \multirow[t]{2}{*}{ CV $(\%)$} & - & 17.0 & 12.5 \\
\hline & \multicolumn{3}{|c|}{ LAR (mg.cm ${ }^{-2} \cdot$ day $\left.^{-1}\right)$} \\
\hline Without treatment (control) & - & $13.4 \mathrm{ab}$ & $50.3 \mathrm{~b}$ \\
\hline $\mathrm{Zn}$ & - & $7.7 \mathrm{~b}$ & $64.9 \mathrm{ab}$ \\
\hline $\mathrm{Zn}+$ Polymer & - & $12.8 \mathrm{ab}$ & $67.3 \mathrm{ab}$ \\
\hline Polymer & - & $16.1 \mathrm{a}$ & $52.8 \mathrm{~b}$ \\
\hline Fungicide & - & $13.9 \mathrm{ab}$ & $56.6 \mathrm{~b}$ \\
\hline Fungicide + Polymer & - & $13.0 \mathrm{ab}$ & $70.3 \mathrm{ab}$ \\
\hline $\mathrm{Zn}+$ Fungicide + Polymer & - & $12.4 \mathrm{ab}$ & $88.6 \mathrm{a}$ \\
\hline Mean & - & 12.3 & 63.8 \\
\hline CV $(\%)$ & - & 17.5 & 18.4 \\
\hline
\end{tabular}

* Means followed by the same letter in the columns do not statistically differ between each other in each variable and period assessed, by Tukey test, at $5 \%$ probability. 
The treatment of seeds with the combination of $\mathrm{Zn}$ +fungicide + polymer has induced higher performance for the FCG variable. Nevertheless, for germination it has been found that this treatment, jointly with the treatment with fungicide alone, also has provided a higher performance than those provided by the remaining treatments. With this, it is possible to infer that use of fungicide, in both the treatments, has reduced incidence of fungi prejudicial to seeds, thus increasing number of normal seedlings. These results disagree from results achieved by Yagi et al., (2006) who have found that the sorghum seeds treated with zinc have presented decrease on germination; as well as from results obtained by Vieira and Moreira (2005) that have also verified alterations on germination of rice seeds coated with zinc. In AA test, performed in this study, it was not found statistically significant effect of treatment on yield; as well as for hectolitric weight (Table 4).

Table 4. Results obtained for the variables: yield (Y); first count of germination (FCG); germination (G), accelerated aging (AA), and hectoliter weight (HW) of wheat seeds produced by plants originating from seeds treated with zinc, fungicide, and polymer.

\begin{tabular}{|c|c|c|c|c|c|}
\hline \multirow{2}{*}{ Treatment } & \multicolumn{5}{|c|}{ Variable assessed } \\
\hline & Y (g.plant $\left.{ }^{-1}\right)$ & FCG $(\%)$ & $\mathrm{G}(\%)$ & $\mathrm{AA}(\%)$ & HW $\left(\mathrm{kg} \cdot \mathrm{hl}^{-1}\right)$ \\
\hline Without treatment (control) & $10.7 b^{*}$ & $67 b^{*}$ & $74 b^{*}$ & $72 a^{*}$ & $78.2 \mathrm{a}^{*}$ \\
\hline $\mathrm{Zn}$ & $14.4 \mathrm{a}$ & $67 \mathrm{~b}$ & $77 \mathrm{~b}$ & $76 \mathrm{a}$ & $76.2 \mathrm{a}$ \\
\hline $\mathrm{Zn}+$ Polymer & $13.6 \mathrm{ab}$ & $68 \mathrm{~b}$ & $85 \mathrm{~b}$ & $74 \mathrm{a}$ & $77.3 \mathrm{a}$ \\
\hline Polymer & $11.2 \mathrm{ab}$ & $67 \mathrm{~b}$ & $84 \mathrm{~b}$ & $77 \mathrm{a}$ & $76.7 \mathrm{a}$ \\
\hline Fungicide & $11.0 \mathrm{~b}$ & $66 \mathrm{~b}$ & $88 \mathrm{a}$ & $74 \mathrm{a}$ & $76.8 \mathrm{a}$ \\
\hline Fungicide + Polymer & $11.5 \mathrm{ab}$ & $68 \mathrm{~b}$ & $82 \mathrm{~b}$ & $78 \mathrm{a}$ & $76.4 \mathrm{a}$ \\
\hline $\mathrm{Zn}+$ Fungicide + Polymer & $13.3 \mathrm{ab}$ & $75 \mathrm{a}$ & $90 \mathrm{a}$ & $75 \mathrm{a}$ & $77.1 \mathrm{a}$ \\
\hline Mean & 12.3 & 68 & 83 & 75 & 76.7 \\
\hline $\mathrm{CV}(\%)$ & 11.6 & 3.4 & 4.1 & 3.7 & 3.1 \\
\hline
\end{tabular}

*Means followed by the same letter in the columns do not statistically differ between each other in each variable assessed, by Tukey tests, at $5 \%$ probability.

Studies related to increment of zinc in seeds and/or grains are of great importance due to innumerous benefits that this micronutrient represents; chiefly the increments on seed quality, and on growth and yield of plants. In addition, deficiency of zinc is responsible for damage on human health, including damages on physical growth, immunological system, learning capacity, and development of cancer (Hotz and Brown, 2004; Prasad et al., 2007).

\section{Conclusions}

Wheat seeds treated with zinc, fungicide, and polymer are positively influenced until 30 days after emergence.

The germination of wheat seeds produced by plants whose seeds had been treated with zinc is positively influenced by treatments with the fungicide alone, and/or with the combination of zinc + fungicide + polymer.

The yield per plant increases when wheat seeds are treated with zinc before sowing.

\section{References}

BARBOSA FILHO, M.P.; DYNIA, J.F.; FAGERIA, N.K. Zinco e ferro na cultura do arroz. Brasília: EMBRAPA-SPI, 1994. 71p. EMBRAPA-CNPAF. (Embrapa - CNPAF. Documentos, 49). http://livraria.sct.embrapa.br/liv_ resumos/pdf/00060870.pdf
BARBOSA FILHO, M.P.; FAGERIA, N.K.; CARVALHO, J.R.P. Fontes de zinco e modos de aplicação sobre a produção de arroz em solos de cerrado. Pesquisa Agropecuária Brasileira, v.17, p.17131719, 1982. http://orton.catie.ac.cr/cgibin/wxis.exe/?isisscript=acervo. xis \&method $=$ post \& formato $=2 \&$ cantidad $=1 \&$ expresion $=m f n=031603$

BERGMANN, W. Colour atlas nutritional disorders of plants. New York: Phosyn, 1992. 386p.

BONNECARRÈRE, R.A.G.; LONDERO, F.A.A.; SANTOS, O; SCHMIDT, D.; PILAU, F.G.; MANFRON, P.A.; NETO, D.D. Resposta de genótipos de arroz irrigado à aplicação de zinco. Revista Faculdade Zootecnia Veterinária e Agronomia, v.10, n.1, p.214-222, 2004. http://revistaseletronicas.pucrs.br/ ojs/index.php/fzva/article/viewfile/2171/1688

BRASIL. Ministério da Agricultura, Pecuária e Abastecimento. Regras para análise de sementes. Ministério da Agricultura, Pecuária e Abastecimento. Secretaria de Defesa Agropecuária. Brasília, DF: MAPA/ACS, 2009. 395p. http://www.agricultura.gov.br/arq_editor/file/laborat\%c3\%b3rio/sementes/ regras $\% 20$ para $\% 20$ analise $\% 20 \mathrm{de} \% 20$ sementes.pdf

COMISSÃO DE QUÍMICA E FERTILIDADE DO SOLO - RS/SC Manual de Adubação e de Calagem para os estados do Rio Grande do Sul e de Santa Catarina. 10.ed. Porto Alegre: NRS/SBCS, 2004. 400p.

CONAB. Central de Informações Agropecuárias: safra de grãos 2010/2011. http://www.conab.gov.br/olalacms/uploads/arquivos/110106084156boletimgraos4olevsafra20102011.pdf. Acess on 28 oct. 2011.

COUTINHO, E.L.M.; NATALE, W.; CONSOLINI, F.; DA SILVA, A.R.; FRANCO, H.C.J. Resposta do milho doce à adubação com zinco. Revista Ecossistemas, v.26, n.2, p.181-186, 2001. http://189.20.243.4/ojs/ ecossistema/viewarticle.php?id=46 
CICERO, S.M.; VIEIRA, R.D. Teste de frio. In: VIEIRA, R.D.; CARVALHO, N.M. (Ed.) Testes de vigor em sementes. Jaboticabal: FUNEP, 1994. p.151-164.

FUNGUETTO, C.I.; PINTO, J.F.; BAUDET, L.; PESKE, S.T. Desempenho de sementes de arroz irrigado recobertas com zinco. Revista Brasileira de Sementes, v.32, n.2. p.117-115. 2010. http://www.scielo.br/scielo. php?pid $=$ s0101-31222010000200014\&script $=$ sci_arttext

GARDNER,F.P.;PEARCE,R.B.;MITCHELL,R.L.Physiologyofcropplants.Ames: IowaStateUniversity Press, 1985.321p.http://www.scielo.br/scielo.php?script=sci nlinks\&ref=000079\&pid=S01013122200400010001400008\&lng=en

GENC, Y.; McDONALD, G.K.; GRAHAM, R. Effect of seed content on early growth of barley (Hordeum vulgare L.) under low and adequade soil zinc supply. Australian Journal of Agricultural Research, v.51, n.1, p.37-45, 2000. http://www.publish.csiro.au/paper/ar99045.htm

HOTZ, C.; BROWN, K.H. Assessment of the risk of zinc deficiency in populations and options for its control. Food and Nutrition Bulletin, v.25, p.94-204, 2004.

LIMA, L.B.; SILVA, P.A.; GUIMARÃES, R.M.; OLIVEIRA, J.A. Peliculização e tratamento de sementes de algodão. Ciência Agrotecnologia, v.30, n.6, p.10911098, 2006. http://www.scielo.br/pdf/cagro/v30n6/a07v30n6.pdf

MACHADO, A.A.; CONCEIÇÃO, A.R. Sistema de análise estatística para Windows. Winstat. Versão 2.0. UFPel, 2003.

NUNES, J.C. Tratamento de semente - qualidade e fatores que podem afetar a sua performance em laboratório. Syngenta Proteção de Cultivos Ltda. 2005. 16p.

OHSE, S.; SANTOS, O.S.; MENEZES, N.L.; SCHMIDT, D. Efeito de fontes e doses de zinco sobre a germinação e o vigor de sementes de arroz irrigado. Revista Brasileira de Sementes, v.19, n.2, p.369-373, 1997. http://www. abrates.org.br/revista/artigos/1997/v19n2/artigo35.pdf.

ORIOLI-JUNIOR, V.; PRADO, R.M.; LEONEL, C.L.; CAZETTA, D.A.; BASTOS, J.C.H.A.G.; QUEIROZ, R.J.B.; SILVEIRA, C.M. Modos de aplicação de zinco na nutrição e na produção de massa seca de plantas de trigo. Revista de la ciencia del suelo y nutrición vegetal, v.8, n.1, p.28-36, 2008. http:// www.scielo.cl/scielo.php?pid=s0718-27912008000100003\&script=sci_arttext
PRADO, R.M.; ROZANE, D. E.; ROMUALDO, L. M.; MOURO, M. C. Acúmulo de nutrientes na parte aérea do milho cv. P30K75 em função da aplicação de fontes de zinco via semente. Revista de Agricultura, v.82, p.127133, 2007. http://www.refdoc.fr/detailnotice?cpsidt=20335178\&traduire=en.

PRASAD, A.S.; BECK, F.W.; BAO, B.; FITZGERALD, J.T.; SNELL, D.C.; STEINBERG, J.D.; CARDOZO, L.J. Zinc supplementation decreases incidence of infections in the elderly: effect of zinco generation of cytokines and oxidative stress. American Journal of Clinical Nutrition. v.85, n.3, p.837-844, 2007. http://bases.bireme.br/cgibin/wxislind.exe/iah/ online/?isisscript $=\mathrm{iah} / \mathrm{iah} . \mathrm{xis} \&$ exprserch $=17344507 \&$ indexserch $=\mathrm{ui} \&$ lang $=\mathrm{i}$

RIBEIRO, N.D.; SANTOS, O.S. Aproveitamento do zinco aplicado na semente na nutrição da planta. Ciência Rural, v.26, p.159-165, 1996. http://www. scielo.br/scielo.php?script=sci_arttext\&pid=s0103-84781996000100030

SANTOS, O.S. Ozinco na nutrição de plantas leguminosas. Lavoura Arrozeira, v.34, n.330, p.26-32, 1981. http://www.scielo.br/scielo.php?script=sci nlinks\&ref $=000149 \&$ pid $=$ s01038478199600010003000036\&lng=en

VIEIRA, E.H.N.; MOREIRA, G.A. Peletização de sementes de arroz. Santo Antônio de Goiás: Embrapa Arroz e Feijão, 2005, 2p. (Embrapa Arroz e Feijão. Comunicado Técnico, 111). http://www.infoteca.cnptia.embrapa.br/ bitstream/doc/214101/1/comt111.pdf

VITTI, G.C.; SERRANO, C.G.E. O zinco na agricultura. $D B O$ Agrotecnologia, v.3, p.10-11, 2007. http://www.anda.org.br/publicacoes

YAGI, R.; SIMILI, F.F.; ARAÚJO, J.C.; PRADO, R.M.; SANCHEZ, S.V.; RIBEIRO, C.E.R; BARRETTO, V.C.M. Aplicação de zinco via sementes e seu efeito na germinação, nutrição e desenvolvimento inicial do sorgo. Pesquisa Agropecuária Brasileira, v.41, n.4, p.655-660, 2006. http://www. scielo.br/pdf/\%0d/pab/v41n4/29813.pdf. 